\title{
Draft genome sequence of Gluconobacter thailandicus NBRC 3257
}

\author{
Minenosuke Matsutani ${ }^{1}$, Haruo Suzuki ${ }^{2}$, Toshiharu Yakushi', Kazunobu Matsushita ${ }^{1}$ \\ ${ }^{1}$ Department of Biological Chemistry, Faculty of Ag riculture, Yamag uchi University, \\ Yamaguchi 753-8515, Japan \\ ${ }^{2}$ Department of Environmental Science and Engineering, Graduate School of Science and \\ Engineering, Yamaguchi University, 1677-1 Yoshida, Yamaguchi, Japan
}

Correspondence: Kazunobu Matsushita (kazunobu@yamaguchi-u.ac.jp) and Haruo Suzuki (haruo@g-language.org)

Keywords: Acetic acid bacteria, Gluconobacter

Gluconobacter thailandicus strain NBRC 3257, isolated from downy cherry (Prunus tomentosa), is a strict aerobic rod-shaped Gram-negative bacterium. Here, we report the features of this organism, tog ether with the draft genome sequence and annotation. The draft genome sequence is composed of 107 contigs for 3, 446, 046 bp with $56.17 \% \mathrm{G}+\mathrm{C}$ content and contains 3,360 protein-coding genes and 54 RNA genes.

\begin{abstract}
Abbreviations: DDBJ- DNA Data Bank of Japan, EMBL- European Molecular Biology Laboratory, NCBI- National Center for Biotechnology Information, AAB- Acetic Acid Bacteria, NJNeig hbor joining, PQQ- Pyrroloqui noline quinone
\end{abstract}

\section{Introduction}

Acetic acid bacteria (AAB) are strictly aerobic Alphaproteobacteria. AAB are well known for their potential to incompletely oxidize a wide variety of sugars and alcohols. The genus Gluconobacter oxidizes a wide range of sugars, sugar alcohols, and sugar acids, and can accumulate a large amount of the corresponding oxidized products in the culture medium [1]. Thus, Gluconobacter strains are widely used for the industrial production of pharmaceutical intermediates, such as L-sorbose (vitamin C synthesis), 6-amino-L-sorbose (synthesis of the antidiabetic drug miglitol), and dihydroxyacetone (cosmetics for sunless tanning) [1]. Furthermore, the genera Acetobacter and Gluconacetobacter are widely used for the industrial production of vinegar because of their high ethanol oxidation ability [2].

To date, six genome sequences of Gluconobacter strains (Gluconobacter oxydans $621 \mathrm{H}$, Gluconobacter oxydans H24, Gluconobacter oxydans WSH-003, Gluconobacter thailandicus NBRC 3255, Gluconobacter frateurii NBRC 101659, and Gluconobacter frateurii NBRC 103465) are available in the public databases [3-8]. These genomic data are useful for the experimental identification of unique proteins or estimation of the phylogenetic relationship among the related strains [9-11].

Gluconobacter thailandicus NBRC 3257 was isolated from downy cherry (Prunus tomentosa) in Japan [12], and identified based on its 16S rRNA sequence [13]. Here, we present a summary of the classification and a set of features of $G$. thailandicus NBRC 3257, together with a description of the draft genome sequencing and annotation.

\section{Classification and features}

A representative genomic $16 \mathrm{~S}$ rRNA sequence of G. thailandicus NBRC 3257 was compared to the 16S rRNA sequences of all known Gluconobacter species type strains. The $16 \mathrm{~S}$ rRNA gene sequence identities between $G$. thailandicus NBRC 3257 and all other type strains of genus Gluconobacter species were 97.58-99.85\%. Gluconobacter species (type strains) exhibiting the highest sequence identities to NBRC 3257 were Gluconobacter frateurii NBRC $3264^{\mathrm{T}}$ and Gluconobacter japonicas NBRC 3271T. Figure 1 shows the phylogenetic relationships of $G$. thailandicus NBRC 3257 to other 
Gluconobacter species in a $16 \mathrm{~S}$ rRNA based tree. All the type strains and ten strains of $G$. thailandicus including NBRC 3257 were used for the analysis [13,17]. Based on this tree, genus Gluconobacter is divided into two sub-groups. Gluconobacter wanchamiae, Gluconobacter cerinus, G. frateurii, G. japonicas, Gluconobacter nephelli, and $G$. thailandicus are classified as clade 1 . On the other hand, Gluconobacter kondonii, Gluconobacter sphaericus, Gluconobacter albidus, Gluconobacter kanchanaburiensis, Gluconobacter uchimurae, Gluconobacter roseus, and Gluconobacter oxydans belong to the clade 2 . All ten $G$. thailandicus strains are closely related to each other, and the $16 \mathrm{~S}$ rRNA sequences have $100 \%$ identities.
Although ethanol oxidation ability is a typical feature of AAB, it is a critical feature that NBRC 3257 lacks the ability to oxidize ethanol because it is missing the cytochrome subunit of the alcohol dehydrogenase complex that functions as the primary dehydrogenase in the ethanol oxidase respiratory chain [18]. Despite its inability to oxidize ethanol, NBRC 3257 can efficiently oxidize many unique sugars and sugar alcohols, such as pentitols, D-sorbitol, D-mannitol, glycerol, mesoerythritol, and 2,3-butanediol [19]. Thus, G. thailandicus NBRC 3257 has unique characteristic features and the potential for the industrial production of many different oxidized products useful as drug intermediates or commodity chemicals.

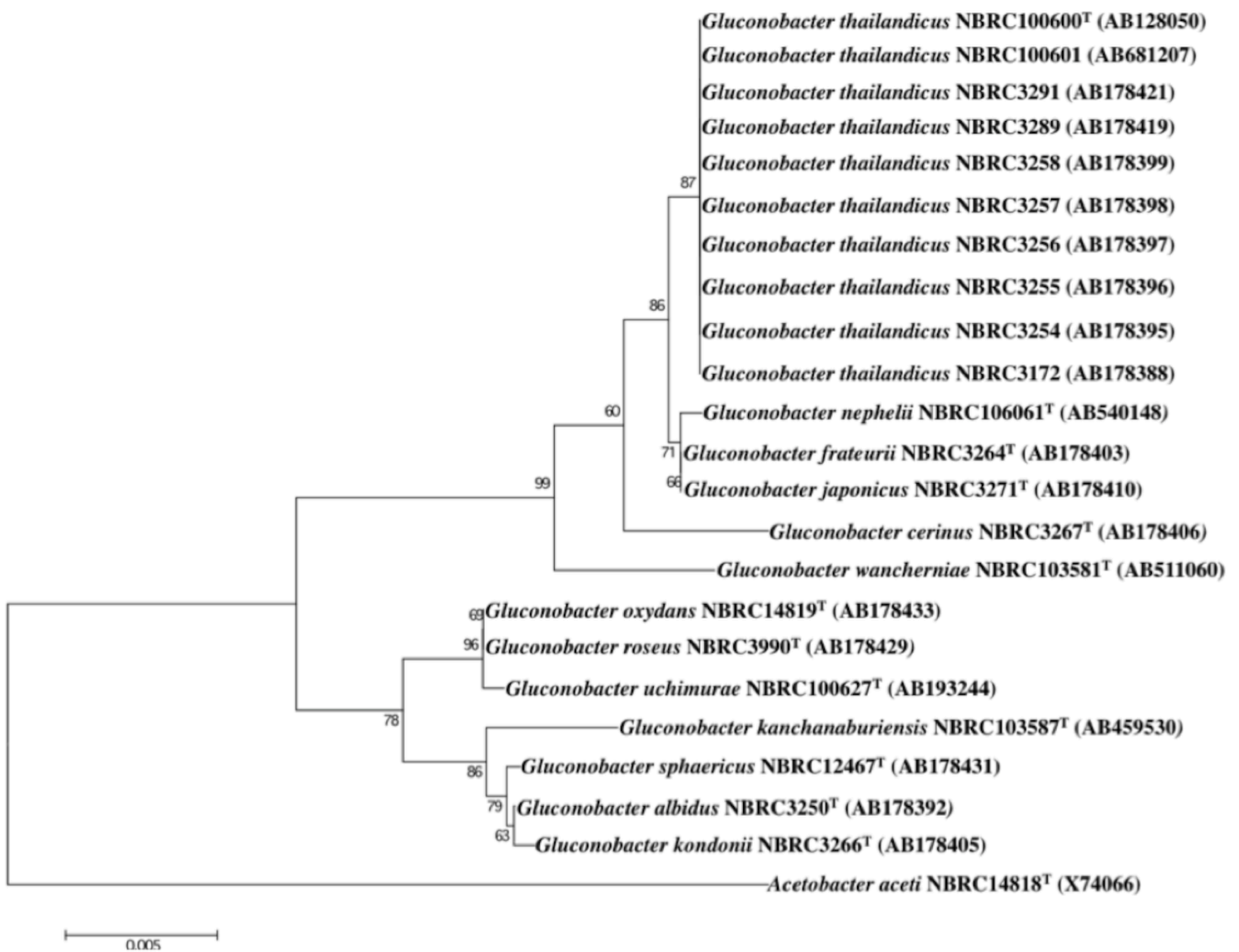

Fig ure 1. Phylogenetic tree highlighting the phylog enetic position of Gluconobacter thailandic us NBRC 3257 relative to other type strains within the Gluconobacter. To construct the phylog enetic tree, these sequences were collected and nucleotide sequence alignment was carried out using CLUSTALW [14]. We used the MEGA version 5.05 package to generate phylogenetic trees based on 16S rRNA genes with the neighbor-joining (NJ) approach and 1,000 bootstrap replicates $[15,16]$. Acetobacter aceti NBRC1481 8 (X74066) was used as the outg roup. 
G. thanilandicus NBRC 3257 is a strictly aerobic, mesophilic (temperature optimum $\approx 30^{\circ} \mathrm{C}$ ) organism. Differential interference contrast image of $G$. thailandicus NBRC 3257 cells grown on mannitol medium (25 g of D-manntiol, $5 \mathrm{~g}$ of yeast extract, and $3 \mathrm{~g}$ of polypeptone per liter) are shown in Figure 2 (A). The cells have short-rod shape with $2.6 \pm$ 0.6 (mean $\pm \mathrm{SD}, \mathrm{n}=10$ ) $\mu \mathrm{m}$ in cell length and $1.2 \pm$ 0.1 (mean \pm SD, $n=10) \mu \mathrm{m}$ in cell width. The flagella stained by the modified Ryu method are shown in Figure 2 (B) and Figure 2 (C) [20]. Singly and multiply flagellated cells were observed frequently. The characteristic features are shown in Table 1.
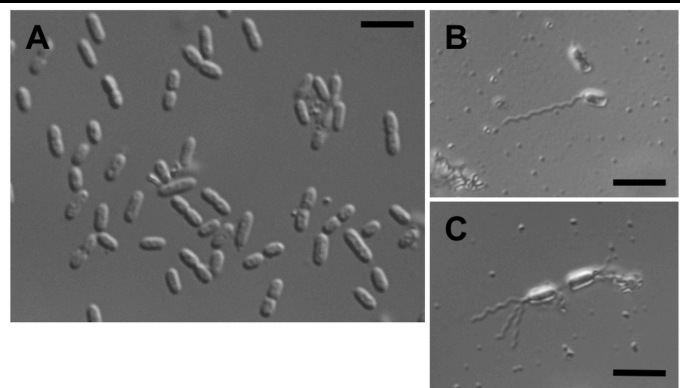

Figure 2. Cell morphology and flagella of G. thailandicus NBRC 3257. (A) Differential interference contrast image of $G$. thailandicus NBRC 3257 grown on mannitol medium. Bar, $5 \mu \mathrm{m}$. (B and C) Microscopic images of flagella stained by the modified Ryu method. Singly (B) and multiply (C) flagellated cells were observed. Bars, $5 \mu \mathrm{m}$.

Table 1. Classification and general features of Gluconobacter thailandicus NBRC 3257 according to the MIGS recommendations [21]

\begin{tabular}{llll}
\hline MIGS ID & Property & Term & Evidence code $^{\mathbf{a}}$ \\
\hline & & Domain Bacteria & TAS [22] \\
& & Phylum Proteobacteria & TAS [23] \\
& Current classification & Class Alphaproteobacteria & TAS $[24,25]$ \\
& & Order Rhodospirillales & TAS [26,27] \\
& & Family Acetobacteraceae & TAS [28,29] \\
& & Spenus Gluconobacter & TAS [27,30,31] \\
& Gram stain & Strain NBRC 3257 & TAS [17,32] \\
& Cell shape & Negative & TAS [23] \\
& Motility & Rod-shaped & IDA \\
& Sporulation & Motile & IDA \\
& Temperature range & Not report & NAS \\
& Optimum temperature & Mesophilic & NAS \\
& Carbon source & Glucose and/or glycerol & IDA \\
Energy source & Glucose and/or glycerol & IDA \\
MIGS-6 & Habitat & Free living & IDA \\
MIGS-6.3 & Salinity & Not report & NAS \\
MIGS-22 & Oxygen & Strict aerobes & NAS \\
MIGS-15 & Biotic relationship & Fruits and Flower & NAS \\
MIGS-14 & Pathogenicity & Non-pathogenic & IDA \\
MIGS-4 & Geographic location & Japan & IDA \\
MIGS-5 & Sample collection time & 1954 & IDA \\
MIGS-4.1 & Latitude & Not report & NAS \\
MIGS-4.2 & Longitude & Not report & NAS \\
MIGS-4.3 & Depth & Not report & NAS \\
MIGS-4.4 & Altitude & Not report & NAS \\
\hline & & & NAS \\
& & NAS \\
\hline
\end{tabular}

Evidence codes - IDA: Inferred from Direct Assay; TAS: Traceable Author Statement (i.e., a direct report exists in the literature); NAS: Non-traceable Author Statement (i.e., not directly observed for the living, isolated sample, but based on a generally accepted property for the species, or anecdotal evidence). These evidence codes are from the Gene Ontology project [33]. If the evidence code is IDA, then the property should have been directly observed, for the purpose of this specific publication, for a live isolate by one of the authors, or an expert or reputable institution mentioned in the acknowledgements. 


\section{Genome sequencing information}

\section{Genome project history}

This genome was selected for sequencing on the basis of its phylogenetic position and 16S rRNA similarity to other members of the Gluconobacter genus. This Whole Genome Shotgun project has been deposited at DDBJ/EMBL/GenBank under the accession BASM00000000. The version described in this paper is the first version, BASM01000000, and the sequence consists of 107 contigs. Table 2 presents the project information and its association with MIGS version 2.0 compliance [34].

\section{Growth conditions and DNA isolation}

The culture of strain NBRC 3257 used to prepare genomic DNA for sequencing was a laboratory stock and grown on $\Delta \mathrm{P}$ medium [35] at $30^{\circ} \mathrm{C}$ with vigorous shaking. The genomic DNA was isolated as described in [36] with some modifications [35]. Three ml of culture broth was used to isolate DNA, and the final DNA preparation was dissolved in 10 $\mathrm{mM}$ Tris- $\mathrm{HCl}(\mathrm{pH} \mathrm{8.0)}$ and $1 \mathrm{mM}$ ethylendiamine tetraacetic acid solution. The purity, quality, and size of the genomic DNA preparation were analyzed by Hokkaido System Science Co., Ltd. (Japan) using spectrophotometer, agarose gel electrophoresis, and Qubit (Invitrogen, Carlsbad, CA) according to the their guidelines.

\section{Genome sequencing and assembly}

The genome of G. thailandicus NBRC 3257 was sequenced using the Illumina Hiseq 2000 sequencing platform by the paired-end strategy $(2 \times 100 \mathrm{bp})$. Paired-end genome fragments were annealed to the flow-cell surface in a cluster station (Illumina). A total of 100 cycles of sequencing-by-synthesis were performed and high-quality sequences were retained for further analysis. The final coverage reached 358-fold for an estimated genome size of $3.44 \mathrm{Mb}$. The sequence data from Illumina HiSeq 2000 were assembled with Velvet ver. 1.2.07 [37]. The final assembly yielded 107 contigs generating a genome size of $3.44 \mathrm{Mb}$. The contigs were ordered against the complete genome of G. oxydans $621 \mathrm{H}$ [3] using Mauve [38-40].

\section{Genome annotation}

Protein-coding genes (ORFs) of draft genome assemblies were predicted using Glimmer version 3.02 with a self-training dataset $[41,42]$. tRNAs and rRNAs were predicted using ARAGORN and RNAmmer, respectively $[43,44]$. Functional assignments of the predicted ORFs were based on a BLASTP homology search against two genome sequences, $G$. thailandicus NBRC 3255 and $G$. oxydans $621 \mathrm{H}$, and the NCBI nonredundant (NR) database [45]. Functional assignment was also performed with a BLASTP homology search against Clusters of Orthologous Groups (COG) databases [46].

Table 2. Project information

\begin{tabular}{lll}
\hline MIGS ID & Property & Term \\
\hline MIGS-31 & Finishing quality & Draft \\
MIGS-28 & Libraries used & Illumina Paired-End library \\
MIGS-29 & Sequencing platforms & Illumina Hiseq 2000 \\
MIGS-31.2 & Fold coverage & $358 \times$ \\
MIGS-30 & Assemblers & Velvet ver. 1.2.07 \\
MIGS-32 & Gene calling method & Glimmer ver. 3.02 \\
& DDBJ ID & BASM00000000 \\
& DDBJ Date of Release & August 08, 2013 \\
& Project relevance & Industrial \\
\hline
\end{tabular}

http://standardsing enomics.org 


\section{Genome properties}

The genome of $G$. thailandicus NBRC 3257 is $3,446,046$ bp long (107 contigs) with a $56.17 \% \mathrm{G}+$ $\mathrm{C}$ content (Table 3 ). Of the 3,414 predicted genes, 3,360 were protein coding genes, and 54 were RNAs ( 3 rRNA genes, and 51 tRNA genes). A total of 2,249 genes $(66.93 \%)$ were assigned a putative function. The remaining genes were annotated as hypothetical genes. The properties and statistics of the genome are summarized in Table 3. The distribution of genes into COG functional categories is presented in Table 4 . Of the 3,360 proteins, 2,669 (79\%) were assigned to COG functional categories. Of these, 245 proteins were assigned to multiple COG categories. The most abundant COG category was "General function prediction only" (342 proteins) followed by "Amino acid transport and metabolism" (247 proteins), "Function unknown" (232 proteins), "Cell wall/membrane/envelope biogenesis" (220 proteins), "Inorganic ion transport and metabolism" (210 proteins), and "Replication, recombination and repair" (201 proteins). The genome map of $G$. thailandicus NBRC 3257 is illustrated in Figure 3, which demonstrates that the pattern of GC skew shifts from negative to positive along an ordered set of contigs with some exceptions. This suggests that the draft genome sequences were ordered almost exactly.

\section{Gene repertoire of $G$. thailandicus NBRC 3257 genome}

Annotation of the genome indicated that NBRC 3257 has membrane-bound PQQ-dependent alco- hol dehydrogenase, adhAB operon (locus_tag NBRC3257_1377 and NBRC3257_1378) and $a d h$ subunit III (NBRC3257_1024). A unique orphan gene of adh subunit I was also identified (NBRC3257_3117). The gene repertories of other membrane-bound PQQ dependent proteins were investigated. Homologous proteins of membranebound PQQ-dependent dehydrogenase (NBRC3257_0292), membrane-bound glucose dehydrogenase (PQQ) (NBRC3257_0371), PQQdependent dehydrogenase 4 (NBRC3257_0662), and PQQ-dependent dehydrogenase 3 (NBRC3257_1743), were identified. In addition, two paralogous copies of the PQQ-glycerol dehydrogenase sldAB operon (NBRC3257_0924 to NBRC3257_0925 and NBRC3257_1134 to NBRC3257_1135) were identified.

It has been thought that the respiratory chains of Gluconobacter species play key roles in respiratory energy metabolism [48-51]. Therefore, the gene repertoires of respiratory chains of NBRC 3257 were also investigated. Besides two type II NADH dehydrogenase homologs (NBRC3257_1995 and NBRC3257_2785) [51], a proton-pumping NADH:ubiquinone oxidoreductase operon (type I NADH dehydrogenase complex) (NBRC3257_2617 to NBRC3257_2629), a cytochrome $o$ ubiquinol oxidase cyoBACD operon (NBRC3257_2304 to NBRC3257_2307), and a cyanide-insensitive terminal oxidase cioAB operon (NBRC3257_0388 to NBRC3257_0389) [48,49], were identified.

Table 3. Nucleotide content and gene count levels of the genome

\begin{tabular}{lrr}
\hline Attribute & Value & \% of total $^{\mathbf{a}}$ \\
\hline Genome size (bp) & $3,446,046$ & - \\
DNA coding region (bp) & $3,118,161$ & 90.48 \\
DNA G+C content (bp) & $1,935,814$ & 56.17 \\
Total genes & 3,414 & 100 \\
RNA genes & 54 & 1.58 \\
Protein-coding genes & 3,360 & 98.42 \\
Genes assigned to COGs & 2,669 & 78.17 \\
\hline
\end{tabular}

a) The total is based on either the size of the genome in base pairs or the total number of protein coding genes in the annotated genome. 


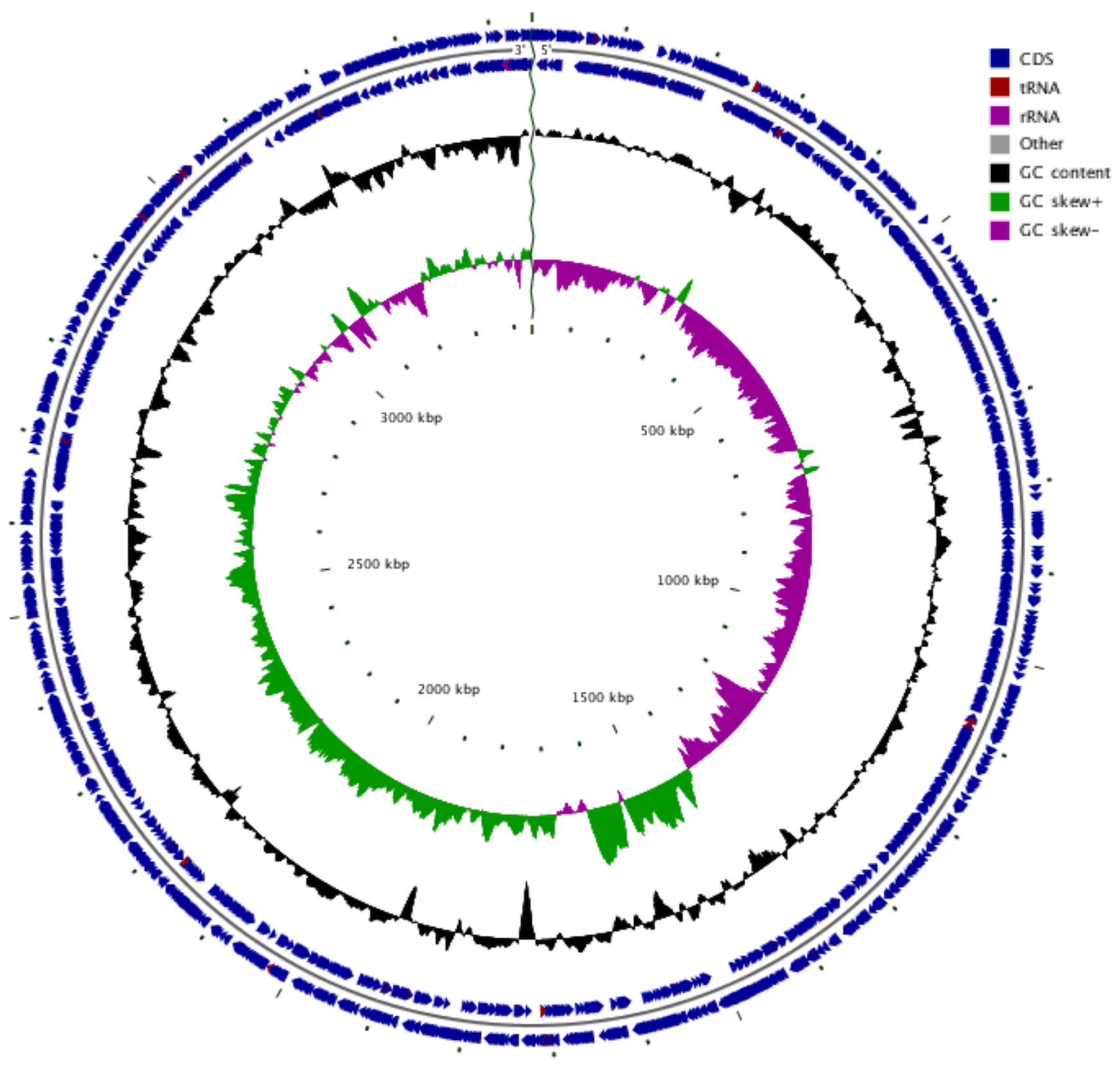

Figure 3. Graphical circular map of a simulated draft Gluconobacter thailandicus NBRC 3257 genome. The simulated genome is a set of contig s ordered against the complete genome of G. oxydans $621 \mathrm{H}$ [3] using Mauve [3840]. The circular map was generated using CGview [47]. From the outside to the center: genes on forward strand, genes on reverse strand, GC content, GC skew. 
Table 4. Number of genes associated with the 25 general COG functional categ ories

\begin{tabular}{|c|c|c|c|}
\hline Code & Value & $\% a^{a} e^{a}$ & Description \\
\hline$J$ & 157 & 4.67 & Translation, ribosomal structure and biogenesis \\
\hline A & 0 & 0.00 & RNA processing and modification \\
\hline K & 190 & 5.65 & Transcription \\
\hline $\mathrm{L}$ & 201 & 5.98 & Replication, recombination and repair \\
\hline B & 0 & 0.00 & Chromatin structure and dynamics \\
\hline $\mathrm{D}$ & 28 & 0.83 & Cell cycle control, cell division, chromosome partitioning \\
\hline Y & 0 & 0.00 & Nuclear structure \\
\hline V & 44 & 1.31 & Defense mechanisms \\
\hline $\mathrm{T}$ & 92 & 2.74 & Signal transduction mechanisms \\
\hline M & 220 & 6.55 & Cell wall/membrane/envelope biogenesis \\
\hline $\mathrm{N}$ & 43 & 1.28 & Cell motility \\
\hline Z & 0 & 0.00 & Cytoskeleton \\
\hline W & 2 & 0.06 & Extracellular structures \\
\hline$U$ & 95 & 2.83 & Intracellular trafficking, secretion, and vesicular transport \\
\hline $\mathrm{O}$ & 120 & 3.57 & Posttranslational modification, protein turnover, chaperones \\
\hline $\mathrm{C}$ & 170 & 5.06 & Energy production and conversion \\
\hline G & 194 & 5.77 & Carbohydrate transport and metabolism \\
\hline $\mathrm{E}$ & 247 & 7.35 & Amino acid transport and metabolism \\
\hline $\mathrm{F}$ & 89 & 2.65 & Nucleotide transport and metabolism \\
\hline $\mathrm{H}$ & 129 & 3.84 & Coenzyme transport and metabolism \\
\hline I & 91 & 2.71 & Lipid transport and metabolism \\
\hline $\mathrm{P}$ & 210 & 6.25 & Inorg anic ion transport and metabolism \\
\hline Q & 64 & 1.90 & Secondary metabolites biosynthesis, transport and catabolism \\
\hline $\mathrm{R}$ & 342 & 10.18 & General function prediction only \\
\hline S & 232 & 6.90 & Function unknown \\
\hline- & 691 & 20.57 & No COG assignment \\
\hline- & 245 & 7.29 & Multiple COG assignment \\
\hline
\end{tabular}

a) The total is based on the total number of protein coding genes in the annotated genome.

\section{Acknowledgement}

This work was financially supported by the Advanced Low Carbon Technology Research and Development Program (ALCA). 


\section{References}

1. Deppenmeier U, Hoffmeister M, Prust C. Biochemistry and biotechnolog ical applications of Gluconobacter strains. Appl Microbiol Biotechnol 2002; 60:233-242. PubMed http://dx.doi.org/10.1007/s00253-002-1114-5

2. Sievers $M$, Teuber $M$. The microbiology and taxonomy of Acetobacter europaeus in commercial vinegar production. J App/ Microbiol 1995; 79:84-95.

3. Prust $C$, Hoffmeister $M$, Liesegang $H$, Wiezer $A$, Fricke WF, Ehrenreich A, Gottschalk G, Deppenmeier U. Complete genome sequence of the acetic acid bacterium Gluconobacter oxydans. Nat Biotechnol 2005; 23:195-200. PubMed http://dx.doi.org/10.1038/nbt1062

4. Ge X, Zhao Y, Hou W, Zhang W, Chen W, Wang J, Zhao N, Lin J, Wang W, Chen $M$ and others. Complete Genome Sequence of the Industrial Strain Gluconobacter oxydans H24. Genome Announc 2013;1(1).

5. Gao L, Zhou J, Liu J, Du G, Chen J. Draft genome sequence of Gluconobacter oxydans WSH-003, a strain that is extremely tolerant of saccharides and alditols. J Bacteriol 2012; 194:4455-4456. PubMed http://dx.doi.org/10.1128//B.00837-12

6. Matsutani M, Kawajiri E, Yakushi T, Adachi O, Matsushita K. Draft Genome Sequence of Dihydroxyacetone-Producing Gluconobacter thailandic us Strain NBRC 3255. Genome Announc 2013; 1:e0011813. PubMed

7. Hattori H, Yakushi T, Matsutani M, Moonmangmee D, Toyama H, Adachi O, Matsushita K. High-temperature sorbose fermentation with thermotolerant Gluconobacter frateurii CHM43 and its mutant strain adapted to higher temperature. Appl Microbiol Biotechnol 2012; 95:1531-1540. PubMed http://dx.doi.org/10.1007/s00253-012-4005-4

8. Sato S, Umemura M, Koike H, Habe H. Draft Genome Sequence of Gluconobacter frateurii NBRC 103465, a Glyceric Acid-Producing Strain. Genome Announc 2013;1(4).

9. Matsutani M, Hirakawa H, Yakushi T, Matsushita K. Genome-wide phylogenetic analysis of Gluconobacter, Acetobacter, and Gluconacetobacter. FEMS Microbiol Lett 2011; 315:122-128. PubMed http://dx.doi.org/10.1111/j.1574$\underline{6968.2010 .02180 . x}$
10. Matsutani M, Hirakawa H, Saichana N, Soemphol W, Yakushi T, Matsushita K. Genome-wide phylogenetic analysis of differences in thermotolerance among closely related Acetobacter pasteurianus strains. Microbiology 2012; 158:229-239. PubMed http://dx.doi.org/10.1099/mic.0.052134-0

11. Peters B, Mientus M, Kostner D, Junker A, Liebl W, Ehrenreich A. Characterization of membranebound dehydrogenases from Gluconobacter oxydans $621 \mathrm{H}$ via whole-cell activity assays using multideletion strains. Appl Microbiol Biotechnol 2013; 97:6397-6412. PubMed http://dx.doi.org/10.1007/s00253-013-4824-y

12. Kondo K, Ameyama M. Carbohydrate metabolism by Acetobacter species. Part I. Oxidative activity for various carbohydrates. Bull Agric Chem Soc Jpn 1958; 22:369-372. http://dx.doi.org/10.1271/bbb1924.22.369

13. Takahashi M, Yukphan P, Yamada Y, Suzuki K, Sakane T, Nakagawa Y. Intrag eneric structure of the genus Gluconobacter analyzed by the $16 \mathrm{~S}$ rRNA gene and 16S-2 3S rRNA gene internal transcribed spacer sequences. J Gen App/ Microbiol 2006; 52:187-193. PubMed http://dx.doi.org/10.2323/jgam.52.187

14. Larkin MA, Blackshields G, Brown NP, Chenna R, McGettigan PA, McWilliam H, Valentin F, Wallace IM, Wilm A, Lopez R, et al. Clustal W and Clustal X version 2.0. Bioinformatics 2007; 23:2947-2948. PubMed http://dx.doi.org/10.1093/bioinformatics/btm404

15. Tamura K, Peterson D, Peterson N, Stecher G, Nei M, Kumar S. MEGA5: molecular evolutionary genetics analysis using maximum likelihood, evolutionary distance, and maximum parsimony methods. Mol Biol Evol 2011; 28:2 731-2739.

PubMed

http://dx.doi.org/10.1093/molbev/msr121

16. Tamura K, Dudley J, Nei M, Kumar S. MEGA4: Molecular Evolutionary Genetics Analysis (MEGA) software version 4.0. Mol Biol Evol 2007; 24:1596-1599. PubMed http://dx.doi.org/10.1093/molbev/msm092

17. Tanasupawat $S$, Thawai $C$, Yukphan $P$, Moonmang mee D, Itoh T, Adachi O, Yamada Y. Gluconobacter thailandicus sp. nov., an acetic acid bacterium in the alpha-Proteobacteria. J Gen Appl Microbiol 2004; 50:159-167. PubMed http://dx.doi.org/10.2323/jgam.50.159 
18. Matsushita K, Nagatani Y, Shinagawa E, Adachi O, Ameyama M. Reconstitution of the ethanol oxidase respiratory chain in membranes of quinoprotein alcohol dehydrog enase-deficient Gluconobacter suboxydans subsp. alpha strains. J Bacteriol 1991; 173:3440-3445. PubMed

19. Adachi O, Fujii Y, Ghaly MF, Toyama H, Shinagawa $\mathrm{E}$, Matsushita K. Membrane-bound quinoprotein D-arabitol dehydrogenase of Gluconobacter suboxydans IFO 3257: a versatile enzyme for the oxidative fermentation of various ketoses. Biosci Biotechnol Biochem 2001;

65:2755-2 762. PubMed http://dx.doi.org/10.1271/bbb.65.2755

20. Kodaka H, Armfield AY, Lombard GL, Dowell VR, Jr. Practical procedure for demonstrating bacterial flagella. J Clin Mic robiol 1982; 16:948-952. PubMed

21. Field D, Garrity G, Gray T, Morrison N, Seleng ut J, Sterk P, Tatusova T, Thomson N, Allen MJ, Angiuoli SV, et al. The minimum information about a genome sequence (MIGS) specification. Nat Biotechnol 2008; 26:541-547. PubMed http://dx.doi.org/10.1038/nbt1360

22. Woese CR, Kandler O, Wheelis ML. Towards a natural system of organisms: proposal for the domains Archaea, Bacteria, and Eucarya. Proc Natl Acad Sci USA 1990; 87:4576-4579. PubMed http://dx.doi.org/10.1073/pnas.87.12.4576

23. Garrity GM, Bell JA, Lilburn T. Phylum XIV. Proteobacteria phyl. nov. In: Garrity GM, Brenner DJ, Krieg NR, Staley JT (eds), Bergey's Manual of Systematic Bacteriology, Second Edition, Volume 2, Part B, Springer, New York, 2005, p. 1.

24. Validation List No. 107. List of new names and new combinations previously effectively, but not validly, published. Int I Syst Evol Microbiol 2006; 56:1-6. PubMed http://dx.doi.org/10.1099/ijs.0.64188-0

25. Garrity GM, Bell JA, Lilburn T. Class I. Alphaproteobacteria class. nov. In: Garrity GM, Brenner DJ, Krieg NR, Staley JT (eds), Bergey's Manual of Systematic Bacteriology, Second Edition, Volume 2, Part C, Springer, New York, 2005, p. 1.

26. Pfennig N, Truper HG. Higher taxa of the phototrophic bacteria. Int J Syst Bacterio/ 1971; 21:1718. http://dx.doi.org/10.1099/00207713-21-1-17

27. Skerman VBD, McGowan V, Sneath PHA. Approved Lists of Bacterial Names. Int J Syst Bacteriol 1980; 30:225-420. http://dx.doi.org/10.1099/00207713-30-1-225
28. Gillis M, De Ley J. Intra- and interg eneric similarities of the ribosomal ribonucleic acid cistrons of Acetobacter and Gluconobacter. Int J Syst Bacteriol 1980; 30:7-27. http://dx.doi.org/10.1099/00207713-30-1-7

29. Henrici AT. The Biology of Bacteria. In: Henrici AT (ed), The Biology of Bacteria, Second Edition, Heath and Co., Chicago, 1939, p. 1-494.

30. Asai T. Taxonomic studies on acetic acid bacteria and allied oxidative bacteria isolated from fruits. A new classification of the oxidative bacteria. Nippon Nogeikagaku Kaishi 1935; 11:674-708. http://dx.doi.org/10.1271/nogeikagaku1924.11.8 $\underline{674}$

31. De Ley J, Frateur J. Genus IV. Gluconobacter Asai 1935, 689; emend. mut. char. Asai, lizuka and Komagata 1964, 100. In: Buchanan RE, Gibbons NE (eds), Bergey's Manual of Determinative Bacteriology, Eighth Edition, The Williams and Wilkins Co., Baltimore, 1974, p. 251-253.

32. Validation List no. 103. Validation of publication of new names and new combinations previously effectively published outside the IJSEM. Int I Syst Evol Microbiol 2005; 55:983-985. PubMed http://dx.doi.org/10.1099/ijs.0.63767-0

33. Ashburner M, Ball CA, Blake JA, Botstein D, Butler H, Cherry JM, Davis AP, Dolinski K, Dwight SS, Eppig JT, et al. Gene ontology: tool for the unification of biology. The Gene Ontology Consortium. Nat Genet 2000; 25:25-29. PubMed http://dx.doi.org/10.1038/75556

34. Field D, Garrity G, Gray T, Morrison N, Seleng ut J, Sterk P, Tatusova T, Thomson N, Allen MJ, Angiuoli SV, et al. The minimum information about a genome sequence (MIGS) specification. Nat Biotechnol 2008; 26:541-547. PubMed http://dx.doi.org/10.1038/nbt1360

35. Kawai S, Goda-Tsutsumi M, Yakushi T, Kano K, Matsushita K. Heterologous overexpression and characterization of a flavoprotein-cytochrome c complex fructose dehydrogenase of Gluconobacter japonicus NBRC 32 60. Appl Environ Microbiol 2013; 79:1654-1660. PubMed http://dx.doi.org/10.1128/AEM.03152-12

36. Marmur J. A procedure for the isolation of deoxyribonucleic acid from microorganisms. Methods Enzymol 1963; 6: 726-738. http://dx.doi.org/10.1016/0076-6879(63)06240-6

37. Zerbino DR, Birney E. Velvet: algorithms for de novo short read assembly using de Bruijn graphs. Genome Res 2008; 18:821-829. PubMed http://dx.doi.org/10.1101/gr.074492.107 
38. Darling AC, Mau B, Blattner FR, Perna NT. Mauve: multiple alig nment of conserved genomic sequence with rearrangements. Genome Res 2004; 14:1394-1403. PubMed http://dx.doi.org/10.1101/gr.2289704

39. Rissman AI, Mau B, Biehl BS, Darling AE, Glasner JD, Perna NT. Reordering contig s of draft genomes using the Mauve aligner. Bioinformatics 2009; 25:2071-2073. PubMed http://dx.doi.org/10.1093/bioinformatics/btp356

40. Darling AE, Mau B, Perna NT. prog ressiveMauve: multiple genome alig nment with gene gain, loss and rearrangement. PLOS ONE 2010; 5:e11147. $\underline{\text { PubMed }}$ http://dx.doi.org/10.1371/journal.pone.0011147

41. Delcher AL, Bratke KA, Powers EC, Salzberg SL. Identifying bacterial genes and endosymbiont DNA with Glimmer. Bioinformatics 2007;

23:673-679. PubMed http://dx.doi.org/10.1093/bioinformatics/btm009

42. Salzberg SL, Delcher AL, Kasif S, White O. Microbial gene identification using interpolated Markov models. Nucleic Acids Res 1998; 26:544548. PubMed http://dx.doi.org/10.1093/nar/26.2.544

43. Laslett D, Canback B. ARAGORN, a program to detect tRNA genes and tmRNA genes in nucleotide sequences. Nucleic Acids Res 2004; 32:11 16. PubMed http://dx.doi.org/10.1093/nar/gkh152

44. Lagesen K, Hallin P, Rodland EA, Staerfeldt HH, Rognes T, Ussery DW. RNAmmer: consistent and rapid annotation of ribosomal RNA genes. Nucleic Acids Res 2007; 35:3100-3108. PubMed http://dx.doi.org/10.1093/nar/g km160

45. Altschul SF, Madden TL, Schaffer AA, Zhang J, Zhang Z, Miller W, Lipman DJ. Gapped BLAST and PSI-BLAST: a new generation of protein database search programs. Nucleic Acids Res 1997;
25:3389-3402. PubMed

http://dx.doi.org/10.1093/nar/25.17.3389

46. Tatusov RL, Natale DA, Garkavtsev IV, Tatusova TA, Shankavaram UT, Rao BS, Kiryutin B, Galperin MY, Fedorova ND, Koonin EV. The COG database: new developments in phylog enetic classification of proteins from complete genomes. Nucle ic Acids Res 2001; 29:22-28. PubMed http://dx.doi.org/10.1093/nar/29.1.22

47. Stothard P, Wishart DS. Circular genome visualization and exploration using CGView. Bioinformatics 2005; 21:537-539. PubMed http://dx.doi.org/10.1093/bioinformatics/bti054

48. Mogi T, Ano Y, Nakatsuka T, Toyama H, Muroi A, Miyoshi H, Mig ita CT, Ui H, Shiomi K, Omura $\mathrm{S}$, et al. Biochemical and spectroscopic properties of cyanide-insensitive quinol oxidase from Gluconobacter oxydans. J Biochem 2009;

146:2 63-2 71. PubMed http://dx.doi.org/10.1093/jb/mvp067

49. Miura H, Mogi T, Ano Y, Mig ita CT, Matsutani M, Yakushi T, Kita K, Matsushita K. Cyanideinsensitive quinol oxidase (CIO) from Gluconobacter oxydans is a unique terminal oxidase subfamily of cytochrome $b d$. J Biochem 2013; 153:535-545. PubMed http://dx.doi.org/10.1093/jb/mvt019

50. Richhardt J, Luchterhand B, Bringer S, Buchs J, Bott M. Evidence for a key role of cytochrome $b_{3}$ oxidase in respiratory energy metabolism of Gluconobacter oxydans. J Bacteriol 2013; 195:4210-4220. PubMed http://dx.doi.org/10.1128//B.00470-13

51. Matsushita K, Ohnishi T, Kaback HR. NADHubiquinone oxidoreductases of the Escherichia coli aerobic respiratory chain. Biochem istry 1987; 26:7732 -7737. PubMed http://dx.doi.org/10.1021/bi00398a029 